\title{
ANALISIS KINERJA KARYAWAN MENGGUNAKAN MULTIVARIATE ADAPTIVE REGRESSION SPLINES
}

\author{
ARNEZDA PUTRI, DODI DEVIANTO, MAIYASTRI \\ Program Studi S1 Matematika, \\ Fakultas Matematika dan Ilmu Pengetahuan Alam, Universitas Andalas, \\ Kampus UNAND Limau Manis Padang, Indonesia. \\ email : arnezdaputri1997@gmail.com,ddevianto@sci.unand.ac.id,maiyastri@sci.unand.ac.id
}

\author{
Diterima 17 Februari 2020 Direvisi 7 Maret 2020 Dipublikasikan 29 April 2020
}

\begin{abstract}
Abstrak. Kinerja karyawan merupakan indikator keberhasilan seseorang secara keseluruhan selama periode tertentu dalam melaksanakan tugas yang diberikan dibandingkan dengan standar hasil kerja yang telah ditentukan dan disepakati bersama. Apabila kinerja karyawan baik maka akan meningkatkan kualitas operasional suatu perusahaan, sebaliknya jika kinerja karyawan kurang baik maka suatu kegiatan operasional perusahaan tidak berjalan dengan maksimal. Oleh sebab itu, perlu dikaji pembentukan model analisis kinerja karyawan terbaik menggunakan metode Multivariate Adaptive Regression Spline (MARS). Metode MARS dapat digunakan pada data berdimensi tinggi dan dapat mengklasifikasikan permasalahan dengan respon biner yang sesuai dengan permasalahan analisa kinerja karyawan yaitu kinerja baik dan kinerja kurang baik. Berdasarkan hasil penelitian diperoleh model MARS terbaik dengan seluruh variabel yang digunakan yaitu kompensasi, budaya organisasi dan motivasi kerja berpengaruh dalam penentuan klasifikasi kinerja karyawan. Ketepatan klasifikasi model yaitu sebesar 98,67 \% dan model yang diperoleh telah konsisten secara statistik.
\end{abstract}

Kata Kunci: Kinerja, Multivariate Adaptive Regression Spline, Klasifikasi

\section{Pendahuluan}

Kinerja karyawan merupakan suatu indikator yang digunakan dalam mengukur pencapaian sumber daya manusia atau karyawan di suatu perusahaan atau organisasi dalam menjalankan kegiatan atau tugas yang telah diberikan [8]. Penilaian kinerja karyawan akan memberikan manfaat bagi suatu organisasi dimana hasil penilaian berfungsi sebagai dasar untuk melakukan evaluasi reguler terhadap kinerja keryawan. Apabila kinerja karyawan baik maka akan meningkatkan kualitas operasional suatu perusahaan yang mengakibatkan kegiatan opersional perusahaan berjalan lancar, sebaliknya jika kinerja karyawan tidak baik maka suatu kegiatan operasional perusahaan tidak akan berjalan lancar dan hasil operasional tidak akan maksimal.

*penulis korespondensi 
Beberapa faktor yang mempengaruhi kinerja karyawan suatu perusahaan yaitu budaya organisasi, kompensasi dan motivasi kerja. Budaya organisasi merupakan aturan atau nilai di dalam suaru organisasi atau perusahaan yang dibentuk oleh pendiri organisasi dan berfungsi untuk mengarahkan anggota organisasi serta diajarkan secara berkesinambungan dari antar setiap anggota organisasi lama ke anggota baru melalui pelatihan.

Kompensasi merupakan bentuk balas jasa yang diberikan oleh suatu perusahaan kepada karyawannya yang dapat berupa uang dan diberikan secara tetap sesuai kesepakatan awal. Motivasi kerja merupakan salah satu yang mendukung karyawan dalam melaksanakan tugasnya sehingga dapat mencapai hasil kerja yang maksimal.

\section{Landasan Teori}

\subsection{Kinerja Karyawan}

Kinerja karyawan merupakan suatu indikator yang digunakan dalam mengukur pencapaian sumber daya manusia atau karyawan di suatu perusahaan atau organisasi dalam menjalankan kegiatan atau tugas yang telah diberikan. Pada pengelompokan kinerja karyawan di suatu perusahaan X, kinerja karyawan dikelompokkan menjadi kinerja karyawan baik apabila nilai motivasi kerja, kompensasi dan budaya organisasi memenuhi kriteria nilai yang telah ditetapkan oleh perusahaan yaitu lebih dari 70. Apabila nilai dari ketiga variabel tersebut kurang dari 70 maka akan dikelompokkan sebagai kinerja karyawan tidak baik.

\subsection{Multivariate Adaptive Regression Splines}

Multivariate Adaptive Regression Splines (MARS) merupakan pendekatan untuk regresi nonparametrik yang dikenalkan oleh Jerome H Friedman pada tahun 1991. Model MARS difokuskan untuk mengatasi permasalahan dimensi yang tinggi yaitu data yang memiliki jumlah variabel prediktor sebesar $3 \leqslant p \leqslant 20$ dan diskontinuitas pada data. MARS merupakan pengembangan dari pendekatan RPR yang menghasilkan model yang tidak kontinu pada knot. Beberapa hal yang perlu diperhatikan dalam membangun model MARS, yaitu [5]:

(1) Knot

Knot merupakan nilai variabel prediktor ketika slope suatu garis regresi mengalami perubahan sehingga knot dapat didefinisikan sebagai akhir dari satu segmen sekaligus merupakan awal dari segmen yang lain [1]. Di setiap titik knot, diharapkan adanya kontinuitas dari fungsi basis antar satu region dengan region lainnya. Minimum observasi antara dua titik knot (MO) yang digunakan sebesar $0,1,2$.

(2) Basis Function (BF)

BF yaitu suatu fungsi yang digunakan untuk menjelaskan hubungan antara variabel respon dengan variabel prediktor. Friedman menyarankan banyaknya maksimum BF adalah 2-4 kali jumlah variabel prediktornya [2].

(3) Maksimum Interaksi (MI)

Interaksi yaitu hasil perkalian silang antar variabel prediktor yang saling berko- 
relasi. Jumlah maksimum interaksi (MI) yang diperbolehkan adalah 1, 2, atau 3. Apabila MI > 3 maka interpretasi model yang dihasilkan akan semakin kompleks dan sulit untuk diinterpretasikan.

Model MARS hasil dari kombinasi antara RPR dan pendekatan splines diperoleh sebagai berikut [2] :

$$
\hat{f}(x)=\alpha_{0}+\Sigma_{m=1}^{M} \alpha_{m} \prod_{k=1}^{K_{m}}\left[s_{k m}\left(x_{v(k, m)}-t_{k m}\right)\right],
$$

dimana :

$\alpha_{0}$ yaitu koefisien konstan fungsi basis, $\alpha_{m}$ yaitu koefisien dari fungsi basis ke- $m, \mathrm{M}$ adalah maksimum fungsi basis, $K_{m}$ yaitu derajat interaksi, $x_{v(k, m)}$ adalah nilai variabel prediktor, $t_{k m}$ nilai $k n o t$ dari variabel prediktor dan $s_{k m}$ bernilai +1 jika knot terletak di sebelah kanan subregion dan bernilai -1 jika knot terletak di sebelah kiri subregion [7].

Pada MARS pemilihan model terbaik ditentukan berdasarkan kriteria Generalized Cross Validation (GCV). Model terbaik yaitu model dengan GCV paling minimum [7]. Fungsi GCV didefinisikan sebagai berikut :

$$
G C V(M)=\frac{\frac{1}{n} \sum_{i=1}^{n}\left(y_{i}-\hat{f}\left(x_{i}\right)\right]^{2}}{\left(1-\frac{C(M)}{n}\right)^{2}}
$$

dengan :

$M$ adalah jumlah fungsi basis, $x_{i}$ adalah variabel prediktor ke- $i, y_{i}$ adalah variabel respon pada pengamatan ke- $i, n$ yaitu banyaknya pengamatan, $\left.\hat{f}_{(} x_{i}\right)$ yaitu nilai taksiran variabel respon pada pengamatan ke- $i$ dan $C(M)$ : Trace $\left[B\left(B^{T} B\right)^{-1} B^{T}\right]+1$.

\subsection{Klasifikasi $M A R S$}

Pada model MARS, klasifikasi didasarkan pada pendekatan analisis regresi. Apabila variabel respon terdiri dari dua nilai, maka dikatakan regresi dengan binary response sehingga dapat digunakan model probabilitas dengan persamaan sebagai berikut [4]:

$$
\begin{aligned}
& P(Y=1)=\pi(x)=\frac{e^{\hat{f}(x)}}{1+e^{\hat{f}(x)}}, \\
& P(Y=0)=1-\pi(x)=\frac{1}{1+e^{\hat{f}(x)}} .
\end{aligned}
$$

Berikut persamaan model MARS respon biner [6]:

$$
\text { logit } \pi(x)=\ln \left[\frac{\pi(x)}{1-\pi(x)}\right]=\alpha_{0}+\Sigma_{m=1}^{M} \alpha_{m} \prod_{k=1}^{K_{m}}\left[s_{k m}\left(x_{v(k, m)}-t_{k m}\right)\right]
$$

Estimasi untuk $\alpha$ ditentukan dengan menggunakan metode kuadrat terkecil [6]. 
Variabel respon memiliki 2 kategori (biner), sehingga digunakan titik potong (cut off) sebesar 0,5 dengan ketentuan apabila $\pi(x) \geq 0,5$ maka hasil prediksi masuk kelompok 1 dan jika $\pi(x)<0,5$ maka hasil prediksi masuk kelompok 0 [2].

\subsection{Ketepatan Klasifikasi Model MARS}

Penentuan kesalahan klasifikasi untuk data respon biner dapat dihitung dengan matriks konfusi (confussion matrix) yang disajikan dalam tabel berikut: dimana

Tabel 1. Matriks Konfusi

\begin{tabular}{|c|c|c|}
\hline \multirow{2}{*}{ Hasil Observasi } & \multicolumn{2}{|c|}{ Hasil Prediksi } \\
\cline { 2 - 3 } & Kelompok I (Y=0) & Kelompok II (Y=1) \\
\hline Kelompok I (Y=0) & $n_{11}$ & $n_{12}$ \\
Kelompok II (Y=1) & $n_{21}$ & $n_{22}$ \\
\hline
\end{tabular}

$n_{11}=$ jumlah observasi Kelompok I yang tepat diklasifikasikan ke Kelompok I $n_{12}=$ Jumlah observasi Kelompok I yang salah diklasifikasikan ke Kelompok II $n_{21}=$ Jumlah observasi Kelompok II yang salah diklasifikasikan ke Kelompok I $n_{22}=$ Jumlah observasi Kelompok II yang tepat diklasifikasikan ke Kelompok II $\mathrm{n}=$ Jumlah observasi

Nilai APER menyatakan proporsi sampel yang salah diklasifikasikan. Nilai APER dihitung sebagai berikut :

$$
A P E R=\frac{n_{12}+n_{21}}{n_{11}+n_{12}+n_{21}+n_{22}} \times 100
$$

Untuk mengetahui kestabilan dalam pengujian maka dapat diuji dengan membandingkan nilai $\operatorname{Press}^{\prime} Q$ dengan nilai tabel Chi Square yang berderajat bebas 1 . Nilai $\operatorname{Press}^{\prime} Q$ diformulasikan sebagai berikut :

$$
\operatorname{Press}^{\prime} Q=\frac{[N-(n k)]^{2}}{N(k-1)}
$$

dimana :

$N$ yaitu jumlah total sampel, $n$ yaitu jumlah observasi yang tepat diklasifikasikan, dan $k$ yaitu jumlah kelompok.

Apabila nilai $\operatorname{Press}^{\prime} Q$ melebihi nilai kritis (tabel $\chi$ kuadrat dengan derajat bebas 1), maka model klasifikasi sudah dapat dianggap stabil dan konsisten secara statistik [3].

\section{Metode Penelitian}

\subsection{Sumber Data}

Data yang digunakan merupakan data suatu perusahaan $X$ yang berjumlah 150 data. 


\subsection{Definisi Variabel}

Variabel respon pada penelitian ini yaitu bernilai 1 untuk kinerja karyawan baik dan bernilai 0 untuk kinerja karyawan kurang baik.

Variabel prediktor pada penelitian ini yaitu:

$X_{1}$ : Kompensasi,

$X_{2}$ : Budaya Organisasi,

$X_{3}$ : Motivasi Kerja.

\subsection{Langkah-Langkah penelitian}

Berikut langkah-langkah dalam penelitian ini, yaitu :

(1) Membuat statistik deskriptif data.

(2) Melakukan pembentukan model klasifikasi MARS dengan langkah sebagai berikut :

(a) Membentuk model klasifikasi MARS dengan melakukan kombinasi antara :

a Maksimum Basis Fungsi (BF) yang digunakan yaitu 22, 33, 44

b Maksimum Interaksi (MI) 1, 2, dan 3

c Minimum Obsevasi (MO) yaitu 0, 1, dan 2 .

(3) Melakukan pemilihan model klasifikasi terbaik berdasarkan model yang menghasilkan nilai GCV paling minimum.

(4) Melakukan interpretasi terhadap model MARS dan tingkat kepentingan variabel prediktor

(5) Mengklasifikasikan data ke dalam matriks konfusi (confussion matrix).

(6) Menghitung ketepatan klasifikasi model MARS dengan menggunakan APER dan menghitung kestabilan model klasifikasi dengan statistik uji Press $^{\prime} Q$.

\section{Pembahasan}

\subsection{Analisa Deskriptif}

Tabel 2. Persentase Kinerja Karyawan Perusahaan X

\begin{tabular}{|c|c|c|}
\hline Kinerja & (\%) Jumlah & Persentase (\%) \\
\hline Baik & 108 & 72 \\
\hline Tidak Baik & 42 & 28 \\
\hline
\end{tabular}

Pada Tabel 2, dapat dilihat sebanyak 72 persen kinerja karyawan perusahaan $\mathrm{X}$ yaitu baik yaitu sebanyak 108 orang karyawan dan 28 persen kinerja karyawan tidak baik yaitu sebanyak 42 orang karyawan.

Pada kelompok kinerja karyawan baik nilai minimum dari ketiga variabel tidak memenuhi kriteria pengelompokan perusahaan $\mathrm{X}$ yaitu $<70$. Rata -rata nilai ketiga variabel $>70$ sehingga sesuai dikelompokkan ke kinerja karyawan baik. Standar 
Tabel 3. Statistik Deskriptif Kinerja Karyawan Baik

\begin{tabular}{|c|c|c|c|c|}
\hline Variabel & Minimum & Maximum & Mean & Standar Deviasi \\
\hline Kompensasi & 62.00 & 87.00 & 75.9633 & 4.08005 \\
\hline Budaya Organisasi & 63.00 & 83.00 & 75.0275 & 4.94686 \\
\hline Motivasi Kerja & 63.00 & 86.00 & 75.2477 & 4.45794 \\
\hline
\end{tabular}

deviasi dari ketiga variabel lebih kecil dari nilai rata-ratanya sehingga keragaman data pada setiap variabel tersebut kecil.

Tabel 4. Statistik Deskriptif Kinerja Karyawan Kurang Baik

\begin{tabular}{|c|c|c|c|c|}
\hline Variabel & Minimum & Maximum & Mean & Standar Deviasi \\
\hline Kompensasi & 50.00 & 76.00 & 66.3415 & 4.90719 \\
\hline Budaya Organisasi & 52.00 & 73.00 & 65.8293 & 4.56565 \\
\hline Motivasi Kerja & 46.00 & 70.00 & 63.8049 & 4.02629 \\
\hline
\end{tabular}

Pada kelompok kinerja karyawan kurang baik nilai maksimum dari ketiga variabel telah memenuhi kriteria pengelompokan perusahaan X yaitu $>70$. Rata - rata nilai ketiga variabel $<70$ sehingga sesuai dikelompokkan ke kinerja karyawan kurang baik. Standar deviasi dari ketiga variabel lebih kecil dari nilai rata-ratanya sehingga keragaman data pada setiap variabel tersebut kecil.

\subsection{Pembentukan Model MARS}

Pada Tabel 5 dapat dilihat hasil pembentukan Model MARS dengan melakukan kombinasi BF, MI dan MO.

Tabel 5. Output Trial and Error Pembentukan Model MARS

\begin{tabular}{|c|c|c|c||c|c|c|c||c|c|c|c|}
\hline BF & MI & MO & GCV & BF & MI & MO & GCV & BF & MI & MO & GCV \\
\hline \hline 6 & 1 & 0 & 0.04460 & 9 & 1 & 0 & 0.03371 & 12 & 1 & 0 & 0.03116 \\
\hline 6 & 2 & 0 & 0.04189 & 9 & 2 & 0 & 0.02723 & 12 & 2 & 0 & 0.01151 \\
\hline 6 & 3 & 0 & 0.04189 & 9 & 3 & 0 & 0.02610 & $\mathbf{1 2}$ & 3 & $\boldsymbol{0}$ & $\mathbf{0 . 0 1 0 9 3} \star$ \\
\hline 6 & 1 & 1 & 0.03895 & 9 & 1 & 1 & 0.03371 & 12 & 1 & 1 & 0.03136 \\
\hline 6 & 2 & 1 & 0.03695 & 9 & 2 & 1 & 0.02769 & 12 & 2 & 1 & 0.01453 \\
\hline 6 & 3 & 1 & 0.03695 & 9 & 3 & 1 & 0.02613 & 12 & 3 & 1 & 0.01453 \\
\hline 6 & 1 & 2 & 0.03895 & 9 & 1 & 2 & 0.03371 & 12 & 1 & 2 & 0.03136 \\
\hline 6 & 2 & 2 & 0.03695 & 9 & 2 & 2 & 0.02769 & 12 & 2 & 2 & 0.01533 \\
\hline 6 & 3 & 2 & 0.03695 & 9 & 3 & 2 & 0.02613 & 12 & 3 & 2 & 0.01533 \\
\hline
\end{tabular}


Pembentukan model MARS dilakukan dengan mengkombinasikan BF, MO dan MI. Model terbaik diperoleh dari hasil kombinasi $\mathrm{BF}=12, \mathrm{MI}=3$, dan $\mathrm{MO}=0$ yang menghasilkan nilai GCV minimum yaitu sebesar 0.01093. Berikut model yang dihasilkan :

$$
\begin{array}{r}
\hat{f}(x)=-0.00379973+0.486652 * B F 5-0.482983 * B F 7 \\
-0.104085 * B F 9+0.0084142 * B F 11
\end{array}
$$

dengan

$$
\begin{array}{ll}
\mathrm{BF} 5=\max (0, \mathrm{X} 3-68) & \mathrm{BF} 9=\max (0, \mathrm{X} 1-69) * \mathrm{BF} 6 \\
\mathrm{BF} 7=\max (0, \mathrm{X} 3-70) & \mathrm{BF} 11=\max (0, \mathrm{X} 2-52) * \mathrm{BF} 9
\end{array}
$$

Berikut beberapa interpretasi pada basis fungsi model MARS terbaik, yaitu :

- $\mathrm{BF} 5=\max (0, \mathrm{X} 3$ - 68); dengan koofisien 0.486652

Risiko karyawan dengan nilai motivasi kerja lebih dari 68 termasuk kelompok kinerja karyawan baik sebesar 1.63 kali dibandingkan karyawan yang memiliki nilai motivasi kerja kurang dari 68

- $\mathrm{BF} 11=\max (0, \mathrm{X} 2$ - 52) * BF9; dengan koofisien 0.0084142

Risiko karyawan dengan nilai budaya organisasi lebih dari 52 dan nilai kompensasi lebih dari 69 termasuk kelompok kinerja karyawan baik sebesar 1.01 kali dibandingkan karyawan yang memiliki nilai budaya organisasi kurang dari 52 nilai kompensasi kurang dari 69 .

Berikut tingkat kepentingan dari stiap variabel prediktor terhadap model terbaik yang diperoleh

Tabel 6. Tingkat Kepentingan Variabel Prediktor

\begin{tabular}{|c|c|c|c|}
\hline Variabel & Definisi Variabel & Tingkat Kepentingan (\%) & -GCV \\
\hline$X_{3}$ & Motivasi Kerja & 100 & 0.20432 \\
\hline$X_{1}$ & Kompensasi & 34.50 & 0.03394 \\
\hline$X_{2}$ & Budaya Organisasi & 15.25 & 0.01543 \\
\hline
\end{tabular}

Tabel 7. Klasifikasi Kinerja Karyawan

\begin{tabular}{|c|c|c|}
\hline \multirow{2}{*}{ Hasil Observasi } & \multicolumn{2}{|c|}{ Hasil Prediksi } \\
\cline { 2 - 3 } & Tidak Baik & Baik \\
\hline Tidak Baik & 41 & 1 \\
\hline Baik & 1 & 107 \\
\hline
\end{tabular}


Pada Tabel 7 dapat diihat hasil pengklasifikasian kinerja karyawan menggunakan model MARS. Ketepatan klasifikasi dari model klasifikasi ini sebesar 98.67 \%. Nilai statistik uji $\operatorname{Press}^{\prime} Q$ yang diperoleh sebesar 142.11 lebih besar daripada nilai $\chi_{(1,0,05)}^{2}$ sehingga dapat dikatakan bahwa pengklasifikasian kelompok kinerja karyawan menggunakan model MARS sudah stabil dan konsisten secara statistik.

\section{Kesimpulan}

Berdasarkan hasil penelitian diperoleh model MARS terbaik untuk klasifikasi kinerja karyawan hasil kombinasi $\mathrm{BF}=12$, $\mathrm{MI}=3$ dan $\mathrm{MO}=0$. Hasil MARS menunjukkan bahwa variabel yang berpengaruh terhadap kinerja karyawan yaitu motivasi kerja, kompensasi dan budaya organisasi dengan tingkat kepentingan variabel berturut-turut adalah $100 \%, 34.5 \%$ dan $15.25 \%$. Model yang diperoleh telah konsisten secara statistik dan dapat mengaklasifikasikan data dengan baik.

\section{Daftar Pustaka}

[1] Eubank, R. L. 1998. Spline Smoothing and Nonparametric Regression. Second edition. New York, Marcel Deker.

[2] Friedman, J. H. 1991. Multivariate Adaptive Regression Splines. The Annals of Statistics. Vol. 19, No.1. Institute of Mathematical Statistics.

[3] Hair, J. F, et. al. 2006. Multivariate Data Analisys. Sixth Edition, Pearson Education Prentice Hall, Inc.

[4] Hosmer, David W. 2000. Applied Logistic Regression Second Edition. Jurnal Statistika, 10(2): $107-120$.

[5] Nash, M. S. dan David F.B. 2001. Parametric and Non Parametric Logistic regression for Prediction of Precense/ Absence of an Amphibian. Las Vegas, Nevada.

[6] Otok, Bambang Widjanarko. 2009. Konsistensi dan Asimtotik Normalitas Model Multivariate Adaptive Regression Spline (Mars) Respon Biner. Jurnal Ilmu Dasar, Vol. 10 No. 2, Juli 2009 : 133 - 140.

[7] Permatasari, P., Devianto, D, Mayastri. 2018. Multivariate Adaptive Regression Splines dan Regresi Kuantil pada Indeks Harga Saham Gabungan Periode 2013-2018. Jurnal Statistika Unimus ,Volume 6:94 - 103.

[8] Rivai, Veithzal dan Fawzi, Ahmad Mohd Basri. 2005. Performance Appraisal: Sistem yang Tepat Untuk Menilai Kinerja Pegawai dan Meningkatkan Daya Saing Perusahaan. Divisi Buku Perguruan Tinggi, PT. Raja Grafindo Persada, Jakarta. 